\title{
KAJIAN BENTUK, FUNGSI, DAN MAKNA UNGKAPAN TRADISIONAL WACANA SORONG SERAH AJI KRAMA DI KABUPATEN LOMBOK BARAT DAN RELEVANSINYA DALAM PEMBELAJARAN MULOK DI SMP
}

\author{
Sihwatik \\ Universitas Mataram \\ Sihwatik425@yahoo.com
}

\begin{abstract}
Abstrak
Ungkapan tradisional merupakan salah satu kekayaan budaya yang terdapat di Lombok Barat terancam punah. Hal itu disebabkan oleh berbagai faktor terutama dengan adanya perkembangan zaman dan pengaruh teknologi. Untuk mencegah terjadinya hal tersebut, perlu dilakukan suatu upaya agar keberadaan ungkapan tradisional tetap terjaga. Adapun yang menjadi sasaran kaji ungkapan tradisional ini adalah meliputi bentuk, fungsi dan makna yang terdapat dalam ungkapan tradisional di daerah Lombok Barat. Teori yang digunakan untuk mengkaji masalah tersebut adalah teori bentuk, fungsi dan makna yang telah dikemukakan oleh berbagai ahli salah satunya adalah teori strukturalisme, teori fungsi dan teori semiotik. Adapun jenis penelitian ini adalah deskriptif kualitatif yaitu mendeskripsikan bentuk, fungsi dan makna serta langkah-langkah untuk mengemas ungkapan tradisional sebagai materi pembelajaran muatan lokal di SMP. Pendeskripsian tersebut dilakukan berdasarkan jumlah ungkapan tradsional (sesenggak) yang terdapat di daerah Sasak pada umumnya dan di daerah kabupaten Lombok Barat pada khusunya. Metode pengumpulan data yang digunakan dalam penelitian ini adalah metode studi pustaka atau studi lapangan, wawancara, observasi, dan perekaman. Diharapkan dari hasil penelitian ini dapat memperluas khasanah ilmu pengetahuan dalam rangka memperkaya bahan referensi bidang kajian dan menambah referensi bagi peneliti lain yang relevan dengan penelitian ini.
\end{abstract}

Kata kunci: Ungkapan tradisional,aji krama, pembelajaran

\begin{abstract}
Sorong Serah Ajikrama text is a traditional idiom which is threathened with extinction. This is caused some factors, one of them because of the influence of globalization era and the high of technology. To prevent this condition, it needs an effort to preserve its. The aim of this traditional idiom description consist of form,function and meaning at west Lombok.the structural theory or function theory and semioyic theory which are released by some experts. The kind of this research is qualitative research. It explines the form, function, meaning and the steps in creating the learning matter in Junior High School (SMP). The description is done based on the numbers of traditional idiom of sorong serah ajikrama text in the whole Lombok Island (Sasaknesh) in general and specifically at West lombok. The method of this reserach is literature study and field study, interview, observation and recording. The result of this research will be useful for upgrading and adding the knowledge, as a reference for the other researchers whose relevance to this research.
\end{abstract}

Keywords: Traditional idiom, Ajikrama, learning.

\section{PENDAHULUAN}

Indonesia merupakan negara yang kaya dengan budaya. Hampir di setiap daerah yang terletak di seluruh penjuru negara Indonesia memiliki budaya berbeda-beda. Hal tersebut disebabkan oleh bentuk negara Indonesia yang terdiri dari beribu-ribu pulau. Selain budaya, Indonesia juga kaya dengan bahasa. Bahasa dan budaya merupakan dua hal yang tidak dapat dipisahkan.

Budaya diciptakan oleh kelompok masyarakat tertentu dengan pertimbangan filosofi yang terkandung di dalamnya. 
Budaya memiliki berbagai macam wujud, salah satunya adalah folklor. Salah satu jenis folklor lisan adalah ungkapan tradisional. Ungkapan tradisional mengandung nilai-nilai baik yang berada di dalam norma agama dan adat istiadat. Warisan budyaa ini harus dijaga dan dilestarikan agar tidak mengalami kepunahan meskipun adanya perkembangan zaman. Perkembangan dan tuntutan zaman telah membawa dampak perubahan besar bagi khazanah kebudayaan daerah, khusunya bagi tatanan kehidupan di masayarakat. Fenomena ini telah mengakibatkan folklor lisan khusunya ungkapan tradisional mengalami pergeseran pemaknaan terhadap unsur-unsur kebudayaan. Hal tersebut disebabkan oleh berbagai faktor, yaitu pemahaman masyarakat tentang ungkapan tradisional yang minim, tidak ada kesadaran masayarakat setempat untuk mejunjung tinggi budayanya, keengganan masyarakat untuk mempelajari ungkapan tradisional tersebut dan masih banyak faktor lainnya.

Ungkapan tradisional banyak dijumpai pada upacara adat istiadat Sasak. Ungkapan tradisional memiliki kekhasan tersendiri, yaitu (1) bahasanya bersifat kromo atau kemuliaan. (2) Menggunakan bahasa Sangsekerta, bahasa Kawi, bahasa Jawa Kuno, bahasa Bali dan bahasa Sasak. (3) Bahasanya diungkapkan dengan bahasa tembang. Upaya menjaga kelestarian kebudayaan lokal tersebut ditempuh dengan mengenalkannya kepada peserta didik me- lalui pendidikan formal khususnya untuk siswa SMP.

Melalui penelitian ini akan dilakukan kajian terhadap ungkapan tradisional Sasak (sesenggak). Kajian ini difokuskan pada bentuk, fungsi, dan makna ungkapan tradisional Sasak. Selanjutnya, hasil kajian tersebut akan dikemas menjadi materi pembelajaran muatan lokal di SMP melalui pengintegrasian beberapa standar kompetensi dan kompetensi dasar sebagi syarat melaksanakan mulok. Peneliti memilih merelevansi dengan pemebelajaran mulok di SMP karena pada siswa SMP merupakan masa peralihan dari anak-anak ke remaja (pubertas). Jadi pada masa tersebut siswa SMP mengalami perkembangan fisik dan pola pikir siswa yang sudah maju atau lebih matang sehingga mereka mudah menerima materi yang disampaikan terutama materi yang berkaitan dengan ungkapan tradisional (sesenggak) pada masyarakat Sasak sebagai materi pembelajaran muatan lokal.

Berdasarkan latar belakang di atas, rumusan masalah yang dapat dikemukakan dalam penelitian ini ialah bagaimanakah bentuk, fungsi, makna ungkapan tradisional Sasak di Lombok Barat dan relevansinya terhadap pembelajaran muatan lokal di Sekolah Menengah Pertama?

Adapun tujuan penelitian ini adalah untuk mengetahui bentuk, fungsi, makna ungkapan tradisional Sasak di Lombok Barat dan relevansinya terhadap pembelaja- 
ran muatan lokal di Sekolah Menengah Pertama.

\section{KONSEP DAN KERANGKA TEORI}

\section{Konsep}

Beberapa konsep yang terkait dalam kajian ini adalah 1) Ungkapan

Tradisional, bahasa yang disampaikan secara lisan atau tertulis dimana tersirat makna dan dapat dijadikan sebagai falsafah dalam hidup bermasyarakat, agar tidak melanggar norma yang berlaku. 2) Suku Sasak, Suku Sasak adalah salah satu suku bangsa yang mendiami suatu daerah di pulau Lombok, termasuk wilayah Provinsi Nusa Tenggara Barat. Suku Sasak mempunyai banyak dialek yang dikembangkan oleh subetnik yang tersebar di wilayah di pulau Lombok. 3) Pembelajaran, proses intraksi peserta didik dengan pendidik dan sumber belajar pada suatu lingkungan belajar.

\section{Kerangka Teori}

Teori strukturalisme merupakan teori yang menitikberatkan perhatiannya pada unsur-unsur pembentuk yang ada dalam teks itu. Kajian stuktural menekankan pada korelasi antara unsur-unsur pembentuk sebuah teks (Badrun, 2006: 4). Pada dasarnya strukturalisme dapat dipandang sebagai susunan hubungan dari susunan suatu benda. Dengan demikian kodrat setiap unsur dalam bagian struktur itu baru mempunyai makna setelah berada dalam hubungannya dengan unsur-unsur lain yang terkandung di dalamnya. Analisis struktural dapat dilakukan dengan mengidentifikasi, mengkaji dan mendeskripsikan fungsi dan hubungan antar unsur yang ada dalam hal yang bersangkutan. Fungsi dari masing-masing unsur itu secara bersama-sama akan membentuk totalitas kemaknaan yang padu (Nurgiyantoro, 2007: 37).

Bentuk atau struktur dapat diartikan juga sebagai argumen atau pengungkapan pikiran. Sebagai sebuah kesatuan unsurunsur ungkapan tradisional tergolong ke dalam bentuk yang bersifat lisan sehingga dalam pengungkapan pikiran dan perasaan. Teori fungsi dipelopori oleh para ahli, di antaranya William R. Bascom, Alan Dundes, dan Ruth Finnegan untuk mengkaji fungsi ungkapan tradisional Sasak di daerah Lombok Barat. Semiotika adalah ilmu yang mempelajari tentang makna yang ada dalam sebuah tanda baik yang berupa teks maupun benda. Kajiannya menekankan pada makna yang terkandung dalam tanda itu. Makna dalam tanda dibangun oleh hubungan sintagmatik dan hubungan paradigmatik. Hubungan sintagmatik adalah hubungan antara tanda dengan tanda. Sedangkan hubungan paradigmatik adalah hubungan antara tanda dengan dunia yang ada di luarnya (Badrun 2006: 8). Menurut Saussure, seperti dikutip Nurgiantoro (2007: 39) tanda sebagai kesatuan dari dua bidang yang tidak dapat dipisahkan. Di mana ada tanda di sana ada sistem. Artinya, sebuah tanda (berwujud kata atau gambar) mempunyai dua aspek yang ditangkap oleh indra kita yang disebut dengan signifier, bidang penanda atau bentuk dan aspek 
lainnya yang disebut signified, bidang petanda atau konsep atau makna. Aspek kedua terkandung di dalam aspek pertama. Teori semiotik akan digunakan untuk mengetahui makna kata ungkapan tradisional Sasak di daerah.

\section{PEMBAHASAN}

\section{A. Bentuk Ungkapan Tradisional dalam Sorong Serah Aji Krama}

Dalam penelitian ini, ada tujuh (7) ungkapan tradisional yang terdapat dalam wacana sorong serah aji krama. Pemilihan kata atau diksi khususnya dalam ungkapan tradisional memberikan nuansa pada makna sehingga kata-kata yang terangkai dalam ungkapan tersebut akan memiliki nilai rasa tertentu. Nilai rasa itu dapat berupa keindahan (estetis) maupun kedalaman makna yang terkandung di dalamnya. Nilai keindahan atau estetis merupakan salah satu unsur penting agar menimbulkan suatu daya tarik tertentu.Hal semacam ini akan membuat seseorang termotivasi untuk menggunakan atau mengetahui ungkapan itu sendiri. Untuk itu, pilihan kata atau diksi yang digunakan tidaklah rumit sehingga mudah dipahami seperti yang terdapat pada tujuh ungkapan di bawah ini.

'pratikile wong akrami' (tata cara berumah tangga)

'duduh warna duduk brana' (bukan rupa bukan harta)

'amung hati kawitane' (hanya hati modalnya)

'hati roro dadi setunggal' (dua hati jadi satu)

'yen gampang luweh gampang' (kalau mudah lebih mudah)

'yen angel, angel kelangkung' (kalau sulit lebih sulit)

'tan hana tinambak harta' (tidak bisa dibeli dengan uang)

Berdasarkan data di atas dapat disimpulkan bahwa ungkapan yang terdapat dalam wacana sorong serah aji krama di atas memiliki bentuk berupa gabungan kata yang membetuk sebuah makna. Gabungan kata tersebut terdiri dari tiga sampai empat kata. Bentuk kata yang digunakan merupakan kata dasar. Jadi, ungkapan yang terdapat dalam wacana sorong serah aji krama merupakan ungkapan dengan bentuk gabungan tiga sampai empat kata dasar yeng membentuk sebuah makna. Pilihan kata yang digunakan cenderung mengarahkan kepada nasihat. Hal ini sesuai dengan tujuan dibacakannya aji krama pada saat sorong serah yaitu untuk memberikan nasihat kepada kedua mempelai yang telah menikah tentang cara berumah tangga dan menyikapi persoalan dalam rumah tangga agar tercipta keluarga yang sakinah mawaddah, warohmah. 


\section{B. Fungsi Ungkapan Tradisional Sasak}

Sorong serah aji krama merupakan suatu tahap yang harus dilalui oleh pasangan pengantin yang sudah menikahpada masyarakat suku sasak. Ungkapan sangat erat penyatuannya dengan kehidupan sosial masyarakat, karena ungkapan berfungsi sebagai sarana penyaluran emosi dari interaksi dengan lingkungan. Namun, dalam ungkapan sorong serah aji krama berfungsi memberikan nasihat kepada pasangan muda -mudi yang baru menikah. Berikut dipaparkan fungsi ungkapan yang terdapat dalam wacana sorong serah aji krama.

\section{Data 01}

'pratikile wong akrami'

(tata cara berumah tangga)

Berdasarkan arti ungkapan di atas dapat dinyatakan bahwa fungsi ungkapan di atas adalah untuk memberitahukan kepada kedua pengantin bahwa dalam mengarungi bahtera rumah tangga memiliki tata cara. Kehidupan berumah tangga merupakan kehidupan baru yang ditempuh oleh sepasang muda-mudi yang telah menikah. Pasangan pengantin yang baru menikah perlu diberikan nasihat dan tata cara dalam mengarungi bahtera rumah tangga agar tidak tererumus ke dalam hal-hal yang dapat merugikan diri dan pasangannya. Kehidupan rumah tangga jelas sangat berbeda dengan kehidupan ketika pasangan pengantin tersebut belum menikah. Untuk itu, agar tidak terjadi sesuatu dalam kehidupan berumah tangga kelak, perlu dibekali dengan pengetahuan tentang cara mengarungi kehidupan berumah tangga.

\section{Data 02}

'duduh warna duduk brana'

(bukan rupa bukan harta)

Berdasarkan arti ungkapan di atas, fungsi dari ungkapan tersebut adalah untuk memberikan nasihat bahwa dalam berumah tangga tidak lagi memikirkan rupa apalagi harta. Sepasang suami istri harus saling menerima kelebihan dan kekurangan masing-masing.Wajah tidak menjamin kebahagiaan dalam berumah tangga. Oleh karena itu, ungkapan ini berfungsi untuk memberitahukan kepada pasangan pengantin baru bahwa wajah tidaklah menjadi ukuran kebahagiaan dalam mengarungi kehidupan berumah tangga. Jadi, sepasang suami istri hendaklah saling menerima dengan segala kelebihan dan keterbatasan masing-masing. Selain itu, dalam ungkapan ini juga menyatakan bahwa harta tidak menjadi ukuran kebahagiaan dalam berumah tangga. Ketika ingin menikah, janganlah memandang harta pasangan karena harta belum tentu membuat seseorang bahagia dalam kehidupan berumah tangga.

\section{Data 03}

'amung hati kawitane'

(hanya hati modalnya)

Berdasarkan arti ungkapan di atas dapat dinyatakan bahwa fungsi ungkapan di atas adalah untuk memberitahukan bahwa dalam memabngun kehidupan rumah tangga 
memerlukan kesiapan hati untuk menghadapi segala permasalahan yang terjadi dalam kehidupan berumah tangga. Kesiapan hati sangat diperlukan dalam kehidupan berumah tangga karena di dalam menjalani kehidupan rumah tangga akan menemukan berbagai kendala dan masalah sehingga membutuhkan kesiapan hati untuk menghadapi masalah tersebut.

\section{Data 04}

'hati roro dadi setunggal'

(dua hati jadi satu)

Ungkapan di atas berfungsi untuk memberitahukan bahwa dalam berumah tangga harus mampu menyatukan hati antara laki-laki dan perempuan. Hal ini bertujuan agar apapun yang terjadi dalam kehidupan berumah tangga kelak, pasangan suami istri dapat menyatukan hati untuk menyelesaikan permasalahan tersebut bersama-sama. Dengan adanya ungkapan ini diharapkan pasangan suami istri yang baru menikah lebih mengutamakan kebersamaan untuk mencapai kehidupan rumah tangga yang diinginkan.

\section{Data 05}

'yen gampang luweh gampang'

(kalau mudah lebih mudah)

Berdasarkan arti ungkapan di atas dapa dinyatakan bahwa ungkapan tersebut berfungsi memberitahukan kepada pasangan pengantin baru bahwa dalam berumah tangga akan menemukan berbagai masalah. Jika pasangan suami istri dapat menyikapi suatu masalah dengan mudah, permasalahn tersebut akan dapat di atasi dengan mudah dan begitu juga sebaliknya. Apabila sepasang suami istri menyikapi suatu masalah dengan sulit, permasalahan tersebut pun akan teras sulit untuk diselesaikan. Jadi, segala permasalahan dalam berumah tangga akan terselesaikan tergantung dari bagaimana cara seseorang menyikapi masalah tersebut.

\section{Data 06}

'yen angel, angel kelangkung'

(kalau sulit lebih sulit)

Ungkapan di atas merupakan ungkapan yang memiliki fungsi untuk memberikan nasihat kepada pengantin bahwa suatu masalah dalam rumah tangga jika sikapi dengan perasaan sulit, masalah tersebut akan menjadi sulit untuk diselesaikan. Oleh karena itu, sebaiknya dalam mengahadapi masalah dalam rumah tangga harus disikapi dengan hati optimis sehingga semua permasalahan dapat diseselesaikan dengan mudah.

\section{Data 07}

'tan hana tinambak harta'

(tidak bisa dibeli dengan uang)

Ungkapan di atas memiliki fungsi untuk memberikan nasihat kepada pasangan pengantin bahwa kesetiaan sebagai pasangan suami istri yang hidup dalam suka maupun duka tidak dapat dihargai dengan harta atau uang. Memiliki suami dan istri yang saling pengertian dan saling 
memahami merupakan modal utama dalam mengarungi kehidupan berumah tangga.

Berdasarkan penejelasan di atas dapat disimpulkan bahwa fungsi ungkapan yang terdapat dalam wacana sorong serah aji krama adalah untuk memberikan nasihat kepada pasangan pengantin yang baru menikah tentang cara kehidupan berumah tangga. Jadi, ungkapan yang terdapat dalam wacana sorong serah aji krama berfungsi memberitahukan kepada pasangan pengantin yang baru saja menikah tentang cara berumah tangga dan cara menyikapi permasalahan yang terjadi dalam rumah tangga. Penyampaian ungkapan ini diharapkan dapat menjadi benteng pertahanan dalam menghadapi badai rumah tangga. Ungkapan yang terdapat dalam wacana sorong serah aji krama sangat sederhana dan mudah dipahami, namun memiliki makna yang sangat dalam dan sangat bermanfaat bagi pasangan pengantin yang hendak mengarungi bahtera rumah tangga.

\section{Makna Ungkapan Tradisional Sasak}

Pada umumnya, ungkapan tradisional Sasak memiliki dua makna kata, yaitu makna denotatif dan makna konotatif. Makna denotatif maksudnya aspek makna kata yang sebenarnya. Sedangkan makna konotatif, maksudnya aspek makna kata yang didasarkan atas perasaan atau pikiran yang timbul. Makna kata tersebut adalah simbol yang berupa bahasa dari ungkapan tradisional dan diterjemahkan secara harfiah dan terjemahan bebas. Berikut dipaparkan makna yang terdapat dalam ungkapan wacana sorong serah aji krama baik secara denotatif maupun konotatif.

\section{Data 01}

'pratikile wong akrami'

(tata cara berumah tangga)

Secara denotatif, ungkapan di atas bermakna ada beberapa cara dalam mengarungi bahtera rumah tangga, tidak sama caranya ketika menjalani hidup sebelum ada pasangan. Makna konotatif yang terdapat dalam ugkapan di atas tidak jauh dengan makna denotatifnya karena menggunakan diksi yang sangat sederhana dan mudah dipahami yaitu bahwa dalam mengarungi bahtera rumah tangga memiliki tata cara. Kehidupan berumah tangga merupakan kehidupan baru yang ditempuh oleh sepasang muda-mudi yang telah menikah. Pasangan pengantin yang baru menikah perlu diberikan nasihat dan tata cara dalam mengarungi bahtera rumah tangga agar tidak tererumus ke dalam halhal yang dapat merugikan diri dan pasangannya. Kehidupan rumah tangga jelas sangat berbeda dengan kehidupan ketika pasangan pengantin tersebut belum menikah. Untuk itu, agar tidak terjadi sesuatu dalam kehidupan berumah tangga kelak, perlu dibekali dengan pengetahuan tentang cara mengarungi kehidupan berumah tangga.

\section{Data 02}

'duduh warna duduk brana' 
(bukan rupa bukan harta)

Makna denotatif ungkapan di atas adalah bahwa dalam berumah tangga tidaklah memandang wajah ataupun harta melainkan karena hati dan saling pengertian. Makna konotatif ungkapan di atas adalah bahwa dalam berumah tangga tidak lagi memikirkan rupa apalagi harta. Sepasang suami istri harus saling menerima kelebihan dan kekurangan masing-masing. Wajah tidak menjamin kebahagiaan dalam berumah tangga. Oleh karena itu, ungkapan ini berfungsi untuk memberitahukan kepada pasangan pengantin baru bahwa wajah tidaklah menjadi ukuran kebahagiaan dalam mengarungi kehidupan berumah tangga. Jadi, sepasang suami istri hendaklah saling menerima dengan segala kelebihan dan keterbatasan masing-masing. Selain itu, dalam ungkapan ini juga menyatakan bahwa harta tidak menjadi ukuran kebahagiaan dalam berumah tangga. Ketika ingin menikah, janganlah memandang harta pasangan karena harta belum tentu membuat seseorang bahagia dalam kehidupan berumah tangga.

\section{Data 03}

'amung hati kawitane'

(hanya hati modalnya)

Makna denotatif ungkapan di atas adalah bahwa di dalam berumah tangga dibutuhkan hati sebagai modal utama, bukan yang lain. Makna konotatif ungkapan di atas adalah bahwa dalam membangun kehidupan rumah tangga memerlukan kesiapan hati untuk menghadapi segala permasalahan yang terjadi dalam kehidupan berumah tangga. Kesiapan hati sangat diperlukan dalam kehidupan berumah tangga karena di dalam menjalani kehidupan rumah tangga akan menemukan berbagai kendala dan masalah sehingga membutuhkan kesiapan hati untuk menghadapi masalah tersebut.

\section{Data 04}

'hati roro dadi setunggal'

(dua hati jadi satu)

Secara denotatif, ungkapan di atas dapat dimaknai sebagai hati sepasang suami istri menyatu untuk mencapai kehidupan rumah tangga yang diinginkan. Sedangkan secara konotatif, makna ungkapan di atas adalah bahwa dalam berumah tangga harus mampu menyatukan hati antara laki-laki dan perempuan. Hal ini bertujuan agar apapun yang terjadi dalam kehidupan berumah tangga kelak, pasangan suami istri dapat menyatukan hati untuk menyelesaikan permasalahan tersebut bersama-sama. Dengan adanya ungkapan ini diharapkan pasangan suami istri yang baru menikah lebih mengutamakan kebersamaan untuk mencapai kehidupan rumah tangga yang diinginkan.

\section{Data 05}

'yen gampang luweh gampang'

(kalau mudah lebih mudah)

Makna denotatif ungkapan di atas adalah 
jika beranggapan bahwa suatu masalah dalam rumah tangga mudah diselesaikan, maka akan terasa mudah untuk menyelesaiknnya. Makna konotatif yang dapat diungkapkan dalam ungkapan di atas yaitu bahwa dalam berumah tangga akan menemukan berbagai masalah. Jika pasangan suami istri dapat menyikapi suatu masalah dengan mudah, permasalahan tersebut akan dapat di atasi dengan mudah dan begitu juga sebaliknya. Apabila sepasang suami istri menyikapi suatu masalah dengan sulit, permasalahan tersebut pun akan teras sulit untuk diselesaikan. Jadi, segala permasalahan dalam berumah tangga akan terselesaikan tergantung dari bagaimana cara seseorang menyikapi masalah tersebut.

\section{Data 06}

'yen angel, angel kelangkung'

(kalau sulit lebih sulit)

Ungkapan di atas merupakan kebalikan dari ungkapan yang terdapat pada data 05 yaitu memiliki makna denotatif bahwa jika menyikapi masalah dalam berumah tangga dengan perasaan suluit, maka akan sulit pula untuk menyelesaikannya. Sedangkan makna konotatif ungkapan di atas adalah bahwa suatu masalah dalam rumah tangga jika sikapi dengan perasaan sulit, masalah tersebut akan menjadi sulit untuk diselesaikan. Oleh karena itu, sebaiknya dalam mengahadapi masalah dalam rumah tangga harus disikapi dengan hati optimis sehingga semua permasalahan dapat diselesaikan dengan mudah.

\section{Data 07}

'tan hana tinambak harta'

(tidak bisa dibeli dengan uang)

Makna denotatif ungkapan di atas adalah bahwa segala bentuk kesetiaan dan pengertian kepada pasangan masing-masing tidak dapat dihargai dengan uang. Makna konotatif yang terdapat dalam ungkapan tersebut adalah bahwa kesetiaan sebagai pasangan suami istri yang hidup dalam suka maupun duka tidak dapat dihargai dengan harta atau uang. Memiliki suami dan istri yang saling pengertian dan saling memahami merupakan modal utama dalam mengarungi kehidupan berumah tangga.

\section{Relevansi Ungkapan dalam Wacana} Sorong Serah Aji Krama terhadap Pembelajaran Muatan Lokal di SMP

Relevansi ungkapan dalam wacana sorong serah aji krama terhadap pembelajaran muatan lokal di SMP ialah dengan menerapkan strategi cooperative learning (kerja kelompok). Langkah-langkah pembelajarannya dibagi menjadi 3 tahap yaitu kegiatan awal, kegiatan inti, dan kegiatan akhir. Setiap kelompok membahas bentuk, fungsi, dan makna yang terkandung dalam ungkapan tradisional Sasak serta membuat nama kelompok berdasarkan nama-nama kebudayaan yang ada di sekitar siswa tersebut. Hal ini dilakukan untuk memperkenalkan berbagai kekayaan budaya khususnya 
budaya lisan kepada siswa didik lebih-lebih untuk siswa sekolah menengah pertama (SMP).

\section{SIMPULAN}

Berdasarkan hasil penelitian dan uraian pada pembahasan di atas, dapat disimpulkan bahwa ungkapan yang terdapat dalam wacana sorong serah aji krama di atas memiliki bentuk berupa gabungan kata yang membetuk sebuah makna. Gabungan kata tersebut terdiri dari tiga sampai empat kata. Bentuk kata yang digunakan merupakan kata dasar. Fungsi ungkapan yang terdapat dalam wacana sorong serah aji krama adalah untuk memberikan nasihat kepada pasangan pengantin yang baru menikah tentang cara kehidupan berumah tangga. Makna yang terkandung dalam ungkapan sorong serah aji krama lebih mengarah kepada nilai-nilai etika dan moral yang harus dilaksanakan dalam kehidupan berumah tangga. Relevansi ungkapan dalam wacana sorong serah aji krama terhadap pembelajaran muatan lokal di SMP ialah dengan menerapkan strategi cooperative learning (kerja kelompok). Langkah-langkah pembelajarannya dibagi menjadi 3 tahap yaitu kegiatan awal, kegiatan inti, dan kegiatan akhir. Setiap kelompok membahas bentuk, fungsi, dan makna yang terkandung dalam ungkapan tradisional Sasak serta membuat nama kelompok berdasarkan nama-nama kebudayaan yang ada di sekitar siswa tersebut. Hal ini dilakukan untuk memperkenal- kan berbagai kekayaan budaya khususnya budaya lisan kepada siswa didik lebih-lebih untuk siswa sekolah menengah pertama (SMP).

\section{UCAPAN TERIMA KASIH}

Penulis mengucapkan terima kasih kepada mitra bestari atas kritikan dan masukan yang membangun untuk perbaikan artikel ini.

\section{DAFTAR PUSTAKA}

Antari , Suwandi. 2004. "Kajian Bentuk, Fungsi, dan Makna Teks Lagu Pop Bali." (Tesis).Bali : Univeristas Udayana

Asri ati, 2004. "Bentuk dan Makna Ungkapan Tradisional Masyarakat Bima.”(Skripsi). Mataram : Universitas Mataram.

Arikunto, Suharsimi. 2010. Prosedur Penelitian. Jakarta: RinekaCipta.

Azwar, Saifuddin. 2010. Metode Penelitian. Yogyakarta: PustakaPelajar.

Badrun, A. 2003. "Patu Mbojo: Struktur, Konteks Pertunjukan, Proses Penciptaan, dan Fungsi."(Disertasi). Jakarta: Universitas Indonesia.

Badara, Aris. 2013. Analisis Wacana. Jakarta: Kencana.

Bungin, Burhan. 2010. Analisis Data Penelitian Kualitatif.Jakarta: PT. Raja Grafindo Persada.

Chaer, A. 2004. Linguistik Umum . Jakarta : PT Rieneka Cipta.

Danandjaja, 1994. A Comparative Study of Japanase and Indonesian Folklore. Harvard : Southeast Asian.

Danadjaja, J. 2007. Folklor Indonesia Ilmu Gosip, Dongeng, dan lain-lain. Jakarta: PT Pustaka Utama Grafit.

Djuroto, T \& Suprijadi, B.2002. Menulis Artikel dan Karya Ilmiah. Bandung : PT. Remaja Rosdakarya.

Dwiloka, B. \& Riana. 2005. Teknik Menulis Karya Ilmiah. Jakarta : PT. Rineka Cipta

Erwan Husnan.2012.Ungkapan Tradisional Masyarakat Sasak.NTB: KRU Prima Guna kerjasama Pusat Studi dan Kajian Budaya.

Ginting, Rosita. 2009 "Nilai dan Fungsi Ndungdugan Karo."(Tesis). Medan : Universitas Sumatra Utara. 
Hadi, Sutrisno. 1993. Metodologi Research. Yogyakarta: Andi Offset.

Ishak , Usman. 2009. "Bentuk dan Makna Ungkapan Tradisional"(Skripsi). Mataram : Universitas Mataram

Kutha Ratna, 2004. Teori, Metode, dan Teknik Penelitian Sastra. Yogyakarta : Pustaka Pelajar.

Kutharatna, Nyoman. 2004. Penelitian Sastra. Denpasar: Pustaka Pelajar.

Lukman.2012. Tata Budaya Sasak Lombok.NTB: KRU Prima Guna kerjasama Pusat Studi dan Kajian Budaya.

Ratmaja, Bahrie, Sudirman.2011.Prosesi Perkawinan Adat Sasak.NTB:KRU Prima Guna kerjasama Pusat Studi dan Kajian Budaya.

Ratmaja, Bahrie, Sudirman.2012. Belajar Menjadi Pembayun. NTB: KRU Prima Guna kerjasama Pusat Studi dan Kajian Budaya.

Mahsun.2005.Metode Penelitian Bahasa. Jakarta : PT Raja Grafindo Persada

Moleong, Cexyj. 1997.Metode Penelitian Kualitatif. Bandung: PT. Remaja Rosdakarya.

Muhammad. 2011. Paradigma Kualitatif Penelitian Bahasa. Yogyakarta: Liebe Book Press.

Pradopo, D. R. 2005. Prinsip-Prinsip Kritik Sastra.Yogyakarta : Gadjah Mada University Press.

Pratama, Bagus.1998. Kamus Ungkapan dan Peribahasa Indonesia. Bandung: Pustaka Setia

Rani, Supratma. 1999. Roman Sastra Indonesia. Bandung: Perpustakaan Setia.
Rahimsyah.2012. Pembelajaran Muatan Lokal. Mataram : Maharani Persada.

Salaqi, Gellis D.2014. "Bentuk, Fungsi dan Makna Lawas Etnik Samawa di Kabupaten Sumbawa dan Relvansinya dalam Pembelajaran Mulok di SMP". (Tesis). Mataram : Universitas Mataram.

Sibarani. 2004. Genolinguistik. Jakarta : Pustaka Pelajar.

Susanto, Dwi. 2012. Pengantar Teori Sastra. Yogyakarta : PT. Buku Seru.

Susilawati .2005. "Bentuk, Fungsi dan Makna Tembang Sorong Serah Aji Krama dalam Perkawinan Adat Sasak Tradisional di Desa Saba Janapria.(Skripsi). Mataram: Unviersitas Mataram.

Sedarmayanti, Hidayat, Syarifuddin. 2011. Metodologi Penelitian. Bandung: CV. Mandar Maju.

Siregar, Syofian. 2011. Statistika Deskriptif untuk Penelitian. Jakarta: PT. Raja Grafindo.

Sugiyono. 2009. Memahami Penelitian Kualitatif. Bandung: Alfabeta.

Suyatno.2004. Teknik Pembelajaran Bahasa dan Sastra. Surabaya: SIC.

Suyatno. 2010. Media Pembelajaran Bandung : PT. Remaja Rosdakarya.

Tanzeh, Ahmad. 2011. Metodologi Penelitian Praktis. Yogyakarta : Sukses Offset

Kalsum Umi.2007.Metalingua Majalah Ilmiah Bahasa dan Sastra.Bandung: Balai Bahasa Bandung

Wahab, Abdul. 1991. Linguistik Pengajaran Bahasa dan Sastra. Surabaya: Airlangga University Press. 